\title{
English in Public Schools Located in Metropolitan Lima, Peru: An Analysis of Eleventh-Grade Students' Level and Perceptions
}

\author{
Andrea I. Morales ${ }^{1}$, Paola S. Palomeque ${ }^{1}$, Valeria Paredes ${ }^{1} \&$ Jerome Mangelinckx $^{1}$ \\ ${ }^{1}$ Universidad Peruana de Ciencias Aplicadas, Lima, Peru \\ Correspondence: Paola S. Palomeque, Universidad Peruana de Ciencias Aplicadas, Lima, Peru. E-mail: \\ sophia.palomeque@gmail.com
}

Received: November 29, 2017

Accepted: April 10, 2018 Online Published: April 12, 2018

doi: 10.5539/elt.v11n5p55

URL: http://doi.org/10.5539/elt.v11n5p55

\begin{abstract}
English Language Teaching (ELT) public policies are present in most of the countries of the Americas due to the importance of said language in the international context. The objective of this research was to know the English level of eleventh-grade students in public schools located in Metropolitan Lima, Peru, as well as their perceptions of their own English learning process within the framework of the new national plan called Inglés, Puertas al Mundo (English, Doors to the World). The sample was composed of 72 students from four schools of the city. This study was conducted using a mixed-method (quantitative-qualitative) approach. The instruments used were a standardized English test (New Inside Out Quick Placement Test) and a structured interview guide. The results revealed that the students' English level is below the level outlined in the national policy. Regarding the perception of their own learning, students have different motivations to learn English, and enjoy the blended model introduced by the national English plan. However, they agree that their English level is very basic and that they would not be able to reach the established communication objectives after graduating from high school.
\end{abstract}

Keywords: English Language Teaching (ELT), blended model, secondary level, public policies

\section{Introduction}

Learning English as a foreign language has a high demand around the world, as it is the international language for business and social interactions (British Council, 2015). In the fifth edition of the Education First English Proficiency Index test - a virtual voluntary evaluation applied worldwide by the aforementioned organization-, Peru was found to have a low level of English (level A2-B1 of the Common European Framework of Reference for Languages [CEFR] designed by the Council of Europe, 2001), and ranked 45th out of 72 countries (Education First, 2016). By the end of 2014, the Peruvian Government announced the new national plan called Inglés, Puertas al Mundo (English, Doors to the World), which would start in 2015 within the framework of the implementation of the Jornada Escolar Completa (JEC, Full School Day) educational service model in 1,000 public secondary schools (with a view to increasing the number of schools in the following years) (Ministerio de Educación del Perú [MINEDU], 2015). Although the plan considers that there may be different English proficiency levels in the same classroom (MINEDU, 2014b), it aims at ensuring that, by 2021, 17\% of high school students will reach CEFR B1 level to be able to graduate (MINEDU, 2014a).

So far, the Ministry of Education of Peru (MINEDU) has reviewed the progress of the plan up to July 2016. Firstly, in relation to the curricular update, teaching hours were increased to five hours of English per week at JEC schools. Secondly, with respect to the strengthening of teaching skills, more than 4,500 English teachers of JEC schools were trained in the blended method (a currently popular method whose effectiveness is being researched by dozens of teachers and other professionals around the world [Alfahadi \& Alsalhi Alshammari, 2015; Chapelle, 2001; Ochoa \& Roberto, 2011]), thereby benefiting more than 500,000 students. In addition, scholarships were awarded both to teachers (to receive training in universities of the United States and the United Kingdom) and students (to study in Peruvian language institutes). Finally, regarding infrastructure, it is known that 1,906 JEC institutions have fully equipped technological English-learning laboratories (MINEDU, 2016d). Nevertheless, the official document of the implementation plan for Inglés, Puertas al Mundo (published in 2016) reveals MINEDU has no data of public school students' English level (MINEDU, 2016c). Therefore, it is also uncertain to what extent the changes introduced by the national plan have impacted students' improvement.

Assessing national educational plans is important to identify what works and which problems need to be addressed 
to enhance its implementation (Nunan, 1992; Cohen, 1994; Richards, 2001). Many countries in the continent already have plans - and even diagnostic studies — of public policies for teaching English as a second language (Mendoza, 2015; Inglés para la competitividad y la movilidad social, 2015; Dirección General de Cultura y Educación de Argentina, 2010). In the same vein, researchers around America have assessed and described ELT policies in their countries. Ramírez-Romero, Pamplón, and Cota (2012) identified the main problems in the implementation of the national English plan in Mexico after a qualitative study conducted on students, parents, teachers, and public-school principals. Mendoza (2015) compared public policies for teaching English as a second language (ESL) in Colombia, Costa Rica, Mexico, and Uruguay, highlighting the importance of the CEFR for the objectives set and the results obtained. Almeida (2016) provided an overview of the Brazilian cities participating in the implementation of English teaching in the first years of primary school. Maldonado-Valentín (2016) offered a discussion related to the impact of language policies regarding the use of Spanish and English in the educational system in Puerto Rico. Furthermore, Porto (2016) described English teaching in public elementary schools in Argentina, and her approach has been materialized in ELT curriculum developments and programs in many of the 24 jurisdictions of the country with different levels of development.

The aim of this study was to know the English level of eleventh-grade students in public schools of Metropolitan Lima, as well as their perceptions about their own learning of the language, having as reference the new national English plan. Due to the sequential explanatory design of the study, we consider that topics were addressed in a comprehensive way, as our objective was not only to determine the students' English level, but also to reflect on the reasons behind the results. Altogether, the results obtained in both stages of this research could be useful to identify the weaknesses of Inglés, Puertas al Mundo and to propose improvements according to the students' perspective.

\subsection{Literature Review}

The following section provides a brief overview of research studies that are related to English Language Teaching (ELT) policies in six countries in Latin America and the Caribbean, namely Chile, Colombia, Costa Rica, Ecuador, Mexico, and Uruguay.

Chile introduced the Programa Inglés Abre Puertas (PIAP, English Opens Doors Program) in 2003, aiming to improve the English language level of students up to the fourth year of secondary school (Banfi, 2015). The Ministry of Education developed strategies for the teachers' continuous professional development and established national standards for English language learning that were consistent with the CEFR (Matear, 2008), in order for students to reach level B1 by the time they graduate from high school (Ministerio Secretaría General de la Presidencia et al., 2014). However, results from the 2016 Chilean National English test showed that only $17 \%$ of students surpassed level B1 upon graduation from high school (Cronquist \& Fiszbein, 2017).

Colombia launched the Programa Nacional de Bilingüismo (National Bilingual Program) in 2004, whose goal was to ensure that students finish high school reaching CEFR level B1 in English by 2019 (Correa \& González, 2016), with a focus on boosting the students' communicative competencies in English, so that they can help the country in the economic and cultural fields (Cárdenas \& Miranda, 2014). Nevertheless, the 2011 Colombian National English test showed that $90 \%$ of high school students who took the exam for the first time barely achieved level A1 upon graduation, whereas only 2\% surpassed level B1 (Sánchez-Jabba, 2013). Four years later, only 3.2\% of senior year high school students reached level B1 (Cronquist \& Fiszbein, 2017), which is an evidence of the little progress that has been made by the English national program.

In Costa Rica, the Plan Nacional de Inglés (English National Plan) was implemented in 2008 with the aim of promoting ELT policies and strategies to help children, teenagers and adults to improve their English language level. In the long term, the country expects $50 \%$ of high school graduates to reach CEFR B2 and C1 levels of English (Quesada, 2013). The first data of Costa Ricans' English level was published in 2012 after a study conducted by the Fundación Costa Rica Multilingüe. The report included the results of an online examination that was applied to more than 8,000 students of public schools around the country, in which $47 \%$ reached level A2, $27 \%$ achieved level B1, and 14\% even surpassed level B2. These results showed that public school students improved their English level after the implementation of the program, as a diagnostic test in 2010 reported that $89 \%$ of students achieved levels A1 and A2 (Mendoza, 2015).

Ecuador has implemented the Proyecto de Fortalecimiento de la Enseñanza del Inglés como Lengua Extranjera (EFL Teaching Reinforcement Project) with clear objectives related to curricular guidelines, textbooks, teachers' training, and the expected outcome of the students' English level, since it aims to ensure that secondary school graduates reach a minimum of CEFR level B1 (Ministerio de Educación de Ecuador, 2017). Gonzalez et al. (2015) conducted a local study in public senior high schools in the Amazon region of Ecuador during the academic year 
2013-2014, in order to find out the students' English proficiency level of listening and speaking skills. The Cambridge English Unlimited Placement Test was applied to 188 students, in which $60 \%$ did not even reach a basic level, 33.33\% achieved a basic level, and 6.67\% reached a low-intermediate level within the CEFR.

Seeking to provide a well-rounded English program to all students in the country, Mexico implemented the Programa Nacional de Inglés en Educación Básica (National English Program in Basic Education) in 2009. This nationwide program displaced the diverse state programs and offered students a uniform curriculum that aimed at ensuring that by the time they graduate, they could reach CEFR level B1 (Ramírez-Romero \& Sayer, 2016; Mexicanos Primero, 2015). Six years after the formal launching of this program, the educational organization Mexicanos Primero prepared the first Examen del Uso y Comprensión del Idioma Inglés para Egresados de Secundaria (EUCIS) (English Usage and Comprehension Test for Secondary School Graduates) and applied it to 4,727 secondary graduates from 11 Mexican cities. The results showed that the goals had not been achieved: only $3 \%$ of students reached the expected level, while $79 \%$ had to be categorized in a non-existent level below A1 (A0) (Mexicanos Primero, 2015).

When it comes to expectations, Uruguay has set one of the highest bars. The program Ceibal en Inglés (Ceibal in English) was launched in 2012 as part of the Ceibal Initiative developed in 2007 in order to implement technology in every class around the country (Plan Ceibal, 2018). Its goal is to ensure that secondary school graduates reach the CEFR level B2 by 2030 (ANEP/CODICEN, 2013). In 2016, an adaptive English test developed by a specialized unit of the British Council was applied to 6,925 seventh-grade students for the first time, and the results varied according to the different skills examined. Regarding reading skills, $26 \%$ of the students reached level A1, whereas 73\% achieved level A2. Regarding listening skills, 35\% reached level A1, 57\% achieved level A2, and only $2 \%$ surpassed level B1. Finally, $59 \%$ of students reached level A1 and only $4 \%$ surpassed level A2 in the written production section (Plan Ceibal, 2017).

\section{Method}

\subsection{Research Design}

This research is a quantitative-qualitative study (sequential explanatory design) - i.e., it had two stages in order to use qualitative data to explore and understand the results obtained from the previously conducted quantitative section. The quantitative part of the study was carried out using a standardized English test, while the qualitative part was carried out using interviews.

In the first stage, the students' English level was assessed by means of a paper-based version of the New Inside Out Quick Placement Test, developed by the international organization Macmillan Publishers (2015). This test measured the students' English level after answering multiple choice questions on vocabulary and grammar, whose results were equivalent to the CEFR levels.

In the second stage, a ten question guide was used to conduct structured interviews with the aim of knowing the students' perception about the English course and their own learning process, having as reference the new national plan. The guide was validated by a research methodology expert by means of a simulation in order to introduce the necessary changes and achieve the study's objectives.

\subsection{Population and Context}

The study was conducted in Metropolitan Lima, which by 2015 had a population of 8,890,792 inhabitants, according to calculations of the Instituto Nacional de Estadística e Informática (National Institute of Statistics and Informatics) (INEI, 2015). Currently, JEC public schools in this region amount to 115 out of the 1,602 which make up the national total (MINEDU, 2016a). The sample chosen was composed of four schools, each one located in one of four of the six geographical areas of Metropolitan Lima: Central Lima, Southern Lima, Eastern Lima, and Northern Lima (Ipsos Apoyo Opinión y Mercado S. A., 2011). This research did not include the geographical areas of Modern Lima and Callao due to accessibility issues.

\subsection{Participants}

\subsubsection{Selection Criteria}

Selection criteria for this study include (a) being an eleventh-grade student in a public school where MINEDU has implemented the JEC, and (b) not having complementary English studies in a language institute because the study focuses on ELT in schools exclusively. Including students with complementary studies would therefore have affected the validity of results.

\subsubsection{Sampling}

With respect to the quantitative component of the research, survey sampling was used-i.e., the English level of all 
students meeting the selection criteria and having their parents' authorization to participate in the study (in case they were minors) was assessed. The participants' selection for the qualitative phase was carried out through purposeful sampling: only one student meeting the selection criteria participated per school-i.e., the total number of participants was four.

\subsubsection{Recruitment}

First, the ten schools shortlisted for the study were contacted via e-mail. The research subject and objectives, as well as the fieldwork to be carried out, were described. If a school was interested in participating, an appointment with the principal of the educational institution would be scheduled to provide information about the study at a deeper level, detailing the students' participation and describing each phase. Finally, the third stage consisted in sending the corresponding informed consent forms to the parents of students who met the selection criteria to inform them about the study and obtain their consent for their children's participation.

The researchers' participation in each educational institution had different stages. Firstly, after receiving the approval to carry out the fieldwork, the principal contacted the English teacher to briefly explain to him/her the study and what the research team would do. Secondly, the day the test was applied, the research team had a meeting with the English teacher for a deeper explanation of the study and the test which would be applied during the hours assigned for his/her class. Then, the research team established direct contact with students to introduce the researchers and the written test.

A total of 72 students who met the selection criteria participated, and only four of them were interviewed. A volunteer was interviewed at each school at the end of the test.

\subsection{Data Collection}

Regarding the first stage, it is necessary to highlight the following considerations: first, only students having their parents' or guardians' authorization could take the written test. Second, the tests were anonymous (a code was assigned to each student). Third, the test was applied in paper and filled out using a pencil. Finally, the test lasted approximately 45 minutes. The research team applied the tests at the institution during the English class hours, and then corrected them with the answer key provided by Macmillan Publishers. The test scores were entered into a spreadsheet in Google Drive.

Regarding the second stage, the interviews were conducted at the participants' educational institution, with prior agreement of parents and school principals. The topics and subtopics to be addressed in the interviews were the following: general perception of the English language, perception of teaching in their school, perception of their learning and performance, and future perspectives regarding the English language. A structured guide was used to conduct the interviews to save time and avoid any setbacks. The interviews were audio recorded (each interview was approximately fifteen minutes long) - with prior knowledge of participants - to facilitate data transcription and interpretation. Then, the audio files were uploaded to Google Drive folders (a code was assigned to each of them according to the geographical area of the interviewee's school).

\subsection{Analysis Plan}

Once the English tests were collected and corrected, the results were entered into a database in Google Drive. To obtain optimal data, the quality of the results obtained was verified during the entering process. The document has four worksheets (one per school). On each sheet, the unique code of each student is shown in rows, while the numerical score and the equivalent CEFR level are shown in columns.

Regarding the second stage, a summary was written immediately after each interview to keep a record of the most relevant aspects. Then, the interviews were transcribed in Word documents.

Once transcripts were completed, a codebook was created. Firstly, the most relevant topics repeatedly mentioned throughout the four interviews were identified. Secondly, these topics became codes. The codebook of this research consists of four codes in total-personal motivation, perception of the teaching method, perception of the English level taught in their schools, and perception of the blended model.

Dedoose was the tool used for qualitative data processing. This consisted in entering the interviews' transcripts to the application and classifying its content based on the codes listed in the codebook. As a result, the set of quotes used in this article was obtained.

After selecting quotes, these were exported from the Dedoose web application to distribute them according to the codes specified in the codebook. It is worth mentioning that an Excel 2013 spreadsheet was used for the export. After obtaining a list of quotes corresponding to each code, it was decided to select those which could be used as evidence for the interviews' interpretation. Then, the quotes were interpreted in a Word 2013 document, where 
summaries of the interviews corresponding to each code were written and quotes were added as examples.

\subsection{Ethical Considerations}

Since most of the participants were minors, ethical considerations were attended. Therefore, students needed to have a consent signed by their parents or guardians to participate in this study to ensure the minors' anonymity.

\section{Results}

Since the objectives of the national plan called Inglés, Puertas al Mundo were set based on CEFR levels, the test applied had to follow the same parameters. According to the concordance table thereof, the beginner level is equivalent to A1 (0-9 points); the elementary level, to A1+ to A2 (10-19 points); the lower intermediate level, to $\mathrm{A} 2+$ to $\mathrm{B} 1$ (20-29 points); the intermediate level, to B1 (30-39 points); the upper intermediate level, to B2 (40-49 points); and the advanced level, to $\mathrm{C} 1$ (50-60 points). The following table shows the sample's test score:

Table 1. Test scores of the study sample according to CEFR levels

\begin{tabular}{lll}
\hline CEFR English Level & Possible Test Score & $\begin{array}{l}\text { Number of students } \\
\text { in each level for the sample } \\
\mathbf{1 0 0 \%}(\mathbf{N}=\mathbf{7 2})\end{array}$ \\
\hline A1 & $0-9$ & $5(6.94 \%)$ \\
A1+ - A2 & $10-19$ & $43(59.72 \%)$ \\
A2+ - B1 & $20-29$ & $24(33.33 \%)$ \\
B1 & $30-39$ & - \\
B2 & $40-49$ & - \\
C1 & $50-60$ & - \\
\hline
\end{tabular}

Note. CEFR $=$ Common European Framework of Reference for Languages.

The sample's mean score is 17.58 points, which corresponds to the level A1+ to A2. Only five students are at level A1, while twenty-four are on track to achieve the national English plan's objective before the end of the school year. Slightly more than half of the sample is at level A1+ to A2. The sample's minimum score obtained was 2 points, while the maximum score was 29 points.

Regarding the interviews with students, the main topics discussed were four: personal motivation, perception of the teaching method, perception of the English level taught in their schools, and perception of the blended model.

Students' motivations to learn English are diverse: personal, professional, or academic. In addition, the interviewees recognize the advantages of learning English, as they consider that it offers new opportunities in different areas of their lives. Firstly, on a personal level, there are two motivational factors which drive them. On the one hand, students enjoy knowing other languages besides Spanish. On the other hand, they want to know other countries, and they are aware that knowing English will allow them to communicate, as it is an international language. This is reflected on the fact that speaking English, as they mention, allows their social circle to expand and to stop being limited only to those who speak Spanish. Thus, they recognize the universality of this language and, therefore, its importance for communicating with others.

"[...] I generally love English because it is another way to discover new places where people only speak that language."-Central Lima Interviewee

"[In] my personal life ... knowing and commanding other languages besides Spanish. That would be important."-Eastern Lima Interviewee

"[The English language is useful] because it can send you to other countries [...]."-Northern Lima Interviewee

"[...] I think it is a language which has been able to stand out a lot because it is used in several countries and it is a universal means of communication besides other languages."- Central Lima Interviewee

"I can also meet a person who only speaks English; I know English, [so] we can communicate."-Northern Lima Interviewee

Firstly, it should be noted that, on a personal level, a minority of the interviewees claimed to have relatives who use English as their only means of communication and, therefore, their motivation is based on being able to 
communicate with them. At the same time, three interviewees consider English as an advantage, since it is a tool for socialization.

"Also, my relatives speak English, so I also want to have some conversation topics and be able to talk to them, to share some things they share with me but sometimes I do not understand. That's why."-Eastern Lima Interviewee

Secondly, on a professional level, most interviewees agree that speaking English has a great influence when getting a job. They mainly mention that it would be a characteristic valued by possible employers who would prefer applicants who master English before those who do not. Thus, they claim that English helps them stand out from others in any work environment.

"Regarding work, English is always a requirement when applying for a job at any ... at any company, they will always require it if you are looking for internationalization."-Eastern Lima Interviewee

"I can speak in English with other people because at work there are people who are not from your country and do not speak your own language, but you can speak their language, so you can communicate."-Northern Lima Interviewee

"It is important to find ..., for example, if you have a job or you are given the opportunity to work, hmm ... I think they hire you because you stand out from other people, so you have more opportunities than you can normally have, hmm... opportunities which maybe you cannot get here, but other people offer them to you because of your skills."-Southern Lima Interviewee

Thirdly, on an academic level, English is one of the main requirements for the higher education programs which half of the interviewees plan to pursue.

"It can help me have a career in which I can use English because most of the study programs I have being doing research on require English, most of them."-Central Lima Interviewee

"I think it is like an important way to be able to get new opportunities to mostly stand out in some subjects or studies, mainly perhaps in higher education."- Southern Lima Interviewee

"II would consider studying English once I finish high school] because of the major I am going to study, Audiovisual Communication and Interactive Media, and because I have always liked English [...]."-Southern Lima Interviewee

Regarding the students' perceptions about the teaching methodology, all interviewees claim that teachers use teaching strategies which facilitate their learning process. Interviewees particularly mention three strategies. The first one is more personal because it focuses on each student. With this strategy, the teacher seeks to reach students by following the new paradigms of modern pedagogy, based on collaborative learning and the various learning styles.

"In my school, teaching ... teachers teach English very well. They do reach students and, if you do not understand, they will help you. They are good."-Northern Lima Interviewee

"It means that the teacher takes a little longer in each topic we address. That is, the teacher explains each word, I mean, they are focusing more on each student."-Eastern Lima Interviewee

The second strategy seeks to use entertainment to get students' attention and keep them focused on the class: the teacher motivates students and awakens their interest in learning English. With this strategy, the teacher uses different dynamic activities which make learning a more motivating, active, and interesting process in comparison with the traditional teaching model. Examples of those dynamic activities are educational games, such as charades. In addition, teachers use songs in English to play games, such as completing the sentence or identifying unknown words.

"[...] I pay attention in class because the teacher makes it very entertaining [...]."-Eastern Lima Interviewee

"[I would highlight] the teacher's teaching [method]. That is, when we arrive and learn about verbs or any word we do not know, she teaches us using dynamic activities. For example, she points out the thing which could be the answer, like charades, and that is how we get the word."-Eastern Lima Interviewee

"[What I would emphasize about the teacher is] that she has new teaching methods. It is not the traditional one which only uses pen and paper. She uses other dynamic games." - Central Lima Interviewee

"For example, the teacher also let us listen to music and identify the words we could ... we know, and that is how we get to remember words."-Eastern Lima Interviewee

Finally, the third strategy is based on the use of additional materials as supporting tools. These materials include 
the book assigned to the English class and the computer they use afterwards.

"[I would highlight] the way they teach us, that is, [using] books, images, and then the computer."-Southern Lima Interviewee

"The teacher is the only one who uses materials and, well, she gives us some work to do."-Northern Lima Interviewee

Despite the above, most interviewees claim the English level taught in their school is basic. This is because every year they see the same topics, which focus on the basic grammar (e.g., verb to be) or vocabulary (e.g., colors and food). Therefore, they would not recommend other people to study in their schools. Likewise, one of the interviewees expresses he would like to be able to further learn English, although MINEDU is responsible for developing the lesson plans.

"[...] because the teacher still teaches us like hmm ... how to say mesa (table) in English, the colors or food in English."-Southern Lima Interviewee

"No, I would not recommend it. I mean, some of my classmates who transferred to other schools told me that, in their new schools, they are learning a little more than what we are supposed to learn here. Maybe we are about to address that topic or maybe we will not address it at all, but they are learning better there."-Eastern Lima Interviewee

"The topic of [lesson] one is the verb to be, and they say the Ministry establishes [the lesson plans] and all that, but I think we could implement something a little more advanced." - Central Lima Interviewee

Interviewees agree that it would be ideal to learn about vocabulary or grammar according to their intellectual capacity as eleventh-grade students or which reflect the actual use of English in everyday life. However, most interviewees agree that repeating topics year after year would not reflect true learning.

"Sometimes [topics] are a bit repetitive and I think that, since this is my last year of high school, I would like to learn something more advanced, deeper, more ... something more focused on skills of [students] our age."-Southern Lima Interviewee

"[...] it seems that we should ... what's the word? ... introduce something new that we do not see [here], something more common in everyday life in places where English is spoken."-Central Lima Interviewee

"[...] such as words slightly more complicated than the ones we have already studied because, as far as I know, every year we repeat topics, and it is the same this year [...]."-Central Lima Interviewee

Interviewees also point out that they will not be able to communicate in English effectively once they finish school because their level will still be basic compared to what has been proposed by the current national English plan, whose goal is that, by 2021, high school students will graduate with an intermediate English level (B1).

"I could deal with basic questions, but I would not be able to continue the conversation."-Eastern Lima Interviewee

"With what they are teaching me? No [I would not be able to communicate in English effectively once I finish school]."-Southern Lima Interviewee

All interviewees highlight the advantages of using computers as a complement for learning English. They claim computers are tools which help expand the teacher's outreach, as they allow students to learn in a self-directed way, whether by using games, exercises, or virtual dictionaries, without the teacher having to be next to them. One of the students mentions that the blended model is an important advantage because, sometimes, the teacher does not have time to help them in a personalized way.

"I think it is an excellent idea because with the computer we can search for, for example, the dictionary, so it is really helpful as the teacher does not need to approach to each student. So, the teacher does not approach to every single student, and instead we can learn better on our own using the computer."-Eastern Lima Interviewee

Furthermore, one of the interviewees points out that this tool allows easy access to the correct pronunciation of words.

"I think it is an excellent way of teaching because you do not only have the help of the virtual dictionary, but you can also see how some words are spelled and you can listen to their correct pronunciation."-Southern Lima Interviewee

However, this is contradicted by the opinion of another interviewee who affirms that, although they practice several English skills, precisely the one related to pronunciation does not receive much attention. 
"We practice grammar, listening, but ... what I have seen only a little bit on the laptop is the correct pronunciation of words."-Center Lima Interviewee

It should be mentioned that the use of computers is limited to the exercises proposed by the school-i.e., students do not have free access to all the online tools possible since computers do not have internet access, but rather only have the default programs which have been installed in them with the information which will be developed progressively throughout the course.

"No, not with the Internet ... It is a site of the institution where we can see the assignments we have to do. It is like this for every unit." - Northern Lima Interviewee

\section{Discussion and Conclusions}

The objective of this research was to know the English level of eleventh-grade students in public schools located in Metropolitan Lima, as well as their perceptions regarding their own learning of the language. Thanks to Macmillan's Quick Placement Test, we found out that more than half of the sample (59.72\%) has an A1+ to A2 level and one third (33.33\%) has an A2+ to B1 level, according to the CEFR. Also, in the interviews, students claimed to have diverse motivations to learn English, and highlighted the role played by teachers and the use of computers in their learning process. However, they also recognized not being satisfied with the level of English taught in their schools, as they would like to be able to communicate effectively in that language for different reasons (personal, academic, or professional). The following is an analysis of the main topics which emerged from this study: English level, communicative capacity in English, and implementation of the blended model.

\subsection{English Level}

The CEFR establishes a common benchmark which allows a country's education authorities—such as the Ministry of Education in Peru - to design a language learning program more effectively (García Santa-Cecilia, 2004). On the one hand, it includes curricular guidelines, assessment tools, and other documents related to the teaching and learning process for language training and acquisition (MINEDU, 2016c). It also describes the thematic units language learners must learn and the skills they must develop to use that language to communicate competently (MINEDU, 2016c). On the other hand, the CEFR defines six levels of language proficiency: A1 and A2 for basic users, $\mathrm{B} 1$ and $\mathrm{B} 2$ for independent users, and $\mathrm{C} 1$ and $\mathrm{C} 2$ for proficient users (Council of Europe, 2001). Since the national English plan establishes level B1 as a target by 2021, it should be noted that level B1 reflects the threshold level specification for a visitor to a foreign country who has the ability to interact in a range of contexts, as well as to cope flexibly with problems in everyday life (Council of Europe, 2001).

Peru has created an English program which has given many people the opportunity to learn a universal language. However, the results of this study show that students have a basic command of English, which is why they may not be able to interact or make themselves understood in different everyday situations. According to the results obtained, none of the students reached the CEFR B1 level, which is the national English plan's target. More than half of the sample $(59.72 \%)$ reached level A1+—beginner level of generative language use, the point at which the learner can interact in a simple way using simple phrases (Council of Europe, 2001) - to A2 - level at which the majority of descriptors stating social functions are to be found (Council of Europe, 2001). Besides, only one-third of the sample (33.33\%) reached level A2+-which represents a strong Waystage performance, and involves more active participation in conversation given some assistance and certain limitations (Council of Europe, 2001) - to B1. Thus, the national plan's target regarding their English level would not be being met. This would demonstrate that improvements are needed to ensure a better progress.

Peru's English language policy has standards and learning outcomes both for students and teachers. However, an obstacle has been identified: no test has been applied to measure the students' or teachers' command of English. In a study on English learning in Latin America, Cronquist and Fiszbein (2017) noted that in Peru it is impossible to identify weaknesses or improvements in the proficiency levels of a language if no tests are applied to students. Moreover, the national plan does not have appropriate tools to assess English teachers' performance (Cronquist \& Fiszbein, 2017). It is important to highlight this weakness since teachers are guides who use all their methodological strategies so that their students achieve a good performance and accuracy when learning another language (Abad \& Toledo, 2006).

Furthermore, Cronquist and Fiszbein (2017) recommended that countries with education policies-such as Peru - assess their English language plans to record their progress. To that effect, a sample larger than that of the present study should be used. The policy framework and impact should be reviewed to identify and overcome the barriers which keep students from learning, as the policy's progress is essential both for English teaching and learning. 


\subsection{Communicative Capacity in English}

The general objective of the national English plan is to develop the students' communicative competencies in English to increase their opportunities in the academic, scientific, technological, and professional fields, as well as to improve the country's human capital, enter international markets, and thus strengthen Peru's competitiveness worldwide (MINEDU, 2016c). In the field of language teaching, communicative competence is defined as the ability a person has to communicate successfully in real-life contexts (Savignon, 1972, cited in Bagarić \& Mihaljević Djigunović, 2007).

As previously mentioned, MINEDU has set level B1 as the minimum level to graduate from high school by 2021 (MINEDU, 2016c). According to the Council of Europe (2001), at level B1, communicative competence involves both listening and speaking skills. With respect to listening skills, level B1 includes "understand[ing] the main points of clear speech on familiar matters encountered in work, school", etc.," as well as "catch[ing] the main point of radio or TV programs on current affairs or topics of interest when the delivery is relatively slow and clear." B1 speaking skills are divided into two areas: spoken interaction and spoken production. On the one hand, spoken interaction involves "deal[ing] with most situations likely to arise while traveling in an area where the language is spoken," as well as "enter[ing] unprepared into conversation on topics that are familiar, of personal interest or pertinent to everyday life." On the other hand, spoken production involves "connect[ing] phrases in a simple way in order to describe experiences, events, hopes, and ambitions," as well as "giv[ing] explanations and narrating a story." Likewise, MINEDU has defined the oral comprehension and production competence as follows: "[The student] can express ideas, opinions, emotions, and feelings on topics of social interest to interact with a native speaker in a fluent way and showing assertiveness during the communication process. Also, [the student] can understand others and convey his/her own stance on topics of interest" (MINEDU, 2017b).

To know the interviewees' perception of their ability to communicate in English effectively after graduating from high school, a specific question regarding this topic was included. Three out of the four interviewees claimed they will not be able to communicate in English after high school, whereas only one of them claimed he/she could hold a basic conversation in English with a foreigner. Two interviewees provided a possible explanation for this problem: learning basic vocabulary and grammar in school might not be enough to communicate in English in an assertive way. The interviewees' answers suggest that students of the Inglés, Puertas al Mundo plan might not be achieving the communicative competence corresponding to level B1. Lesson plans include activities which allow students to attain the expected communicative competence, such as real group surveys or short conversations in pairs (MINEDU, 2017c). However, the interviewees' perception shows that classes might not be successful in practice.

\subsection{Implementation of the Blended Model}

MINEDU decided to implement the blended model in class to attain its general objective - preparing students to have a good command of English which meets the needs created by globalization (MINEDU, 2017a). Moskal, Dziuban and Hartman (2012) raised the question whether blended learning was a "dangerous idea", citing Seife (2000), who claims this model challenges the status quo, as it maintains traditional teaching while encouraging the adoption of new platforms and resources. Yasar and Demirkolb (2014) state that the blended model is an online and face-to-face teaching model, whereas MINEDU (2016b) defines it as an efficient way in which the teacher combines different teaching methods while considering the students' learning styles. In the Peruvian educational context, this model has been implemented to complement face-to-face learning and address the disadvantages of online learning, such as the lack of interaction with other students and the teacher. The blended model is presented in the Manual del acompañante especializado en inglés (English Instructor's Manual) as an opportunity for students to access various sources of knowledge with more freedom in terms of time and space (MINEDU, 2016b). Said document also indicates that the blended model help create a customized space where students with different English levels can make progress at a suitable pace for them, as well as participate in their learning process in a more active and responsible way. In this context, the teacher plays a secondary role - a guide who must be able to use new technologies and make the most of the resources provided by the Ministry through educational institutions.

The aim of the interviews conducted was to know the students' perception regarding the use of computers in their activities and its effectiveness for learning. All interviewees acknowledged that computers are a helpful learning tool, and they highlighted their importance. Two of them claim they improve the teacher's performance, as he/she does not always have enough time to provide the personalized assistance students might need. Interviewees also claimed that the information provided by teachers could sometimes be incorrect and they would be making mistakes in English, whereas the information provided by the virtual platform is indeed correct. Furthermore, two 
of the interviewees claimed that the activities might be too basic for their level, which means the teacher would be using a platform for a level lower than B1 (possibly due to the students' low level). They also claimed that some problems arise while carrying out the activities, as the system automatically shows the answers. This could be troublesome for evaluations and could distort the students' real learning process, as they could simply copy the answers provided by the system.

It is clear then that implementing the blended model is an important step towards the objective set by MINEDU, as the teacher becomes a facilitator and students are more autonomous. However, the blended model needs to be implemented after a careful study of the students' needs and expectations to ensure the use of appropriate technology (Morales \& Ferreira, 2008). Furthermore, MINEDU needs to continue providing teachers with training on the language and the use of platforms. In addition to this, teachers should also have the opportunity to exchange their views on the implementation of new technologies, so that their attitude throughout the process can be positive and can contribute to the students' satisfaction (Hernandez, 2014). Moreover, another aspect to be highlighted is that, regardless of what the public policy states, teachers will continue adapting the course content to their students' real level if no diagnostic study is carried out. In short, the students' level and perceptions regarding communicative competence and online English learning suggest there is a gap between the objective set by MINEDU and the students' real level. The results of this study show that it might be necessary to conduct a diagnostic study for identifying the barriers to achieving the objective and to propose corrective measures in the future.

While this study was conducted at local level—in four schools in Lima, Peru — the results obtained could be a starting point for future research. Therefore, we think our sample is suitable to fulfil the objectives set for this study. Nonetheless, the small number of students may not be representative of the student population participating in the program nationwide. Moreover, as previously mentioned, schools were chosen to cover four out of the six geographical areas of Metropolitan Lima, which would give us a first look of the sample in terms of representativeness. Due to these two reasons, the results of this study cannot be taken as strong evidence of the level or perceptions of the population studied as a whole. Besides, the standardized test applied for this study presents another limitation: though the paper-based New Inside Out Quick Placement Test is a tool developed by the international organization Macmillan Publishers, it only tests grammar and vocabulary skills. Due to the various aspects covered by the national English plan, it would have been more appropriate to use a tool which tests the four general skills (speaking, listening, reading, and writing).

This study might serve as a starting point to justify the need for a diagnostic study to then take action from the teaching point of view and identify which changes could be made in the national English plan. Since MINEDU does not have baseline data, it would be advisable to make this first step before designing an ELT program of this scale, as the instruments and evaluations should be in line with the students' reality. Even though the method applied for this study could be used in other geographical contexts of Peru, a comprehensive nationwide diagnostic study should be carried out by MINEDU, as the educational policy covers the entire Peruvian territory and not only Metropolitan Lima. Furthermore, it would be interesting to conduct a study which measures English levels in different Peruvian regions while taking into account factors such as the mother tongue, the geographical context, and socio-economic situation, among others.

The national plan called Inglés, Puertas al Mundo aims at improving the English level of Peruvians, as well as their communication skills in that language. This study found that the sample of eleventh-grade students reached the CEFR A1+ to A2 level. Thus, according to these results, corrective measures or modifications to the program's design should be introduced to achieve the objectives set. ELT public policies in Peru and other countries in Latin America have become increasingly relevant due to the current context of globalization. Even though these programs are developed with the advice of educational experts, previous studies have shown that the plans' objectives have not been fulfilled. In order to reach the English level stated in the national plan, the focus should not only be put on the students' learning and future expectations. Attention should also be given to the teachers' access to formal education (ELT pedagogical training), the proper use of new technologies in the classroom, and the evaluation of students and teachers' progress. This will allow for a diagnosis of the current situation of ELT in public schools in Peru to then implement an efficient plan.

\section{References}

Abad, M., \& Toledo, G. (2006). Factores clave en la enseñanza de español como lengua extranjera (E/LE). Onomázein, 13(1), 135-145.

Alfahadi, A., Alsalhi, A., \& Alshammari, A. (2015). EFL secondary school teachers' views on blended learning in Tabuk city. English Language Teaching, 8(9), 51-85. https://doi.org/10.5539/elt.v8n9p51 
Almeida, R. (2016). ELT in Brazilian public schools: History, challenges, new experiences and perspectives. Education Policy Analysis Archives, 24(81), 1-22. https://doi.org/10.14507/epaa.24.2473

ANEP/CODICEN - Programa de Políticas Lingüísticas. (2013). Acuerdo de certificación oficial de idioma inglés. Retrieved from http://www.anep.edu.uy/plinguisticas/phocadownload/documentos/firma\%20contrato\%20 anep-\%20universidad\%20de\%20cambridge\%20\%2025-11-13.pdf

Bagarić, V., \& Mihaljević Djigunović, J. (2007). Defining communicative competence. Metodika, 8(14), 94-103.

Banfi, C. (2015). English language teaching expansion in South America: Challenges and opportunities. In L. D. Kamhi-Stein, G. Diaz Maggioli, \& L. C. de Oliveira (Eds.) English language teaching in South America: Policy, preparation, and practices. Clevedon: Multilingual Matters.

British Council. (2015). English in Peru: An examination of policy, perceptions and influencing factors. Retrieved from https://ei.britishcouncil.org/sites/default/files/latin-america-research/English\%20in\%20Peru.pdf

Cárdenas, R., \& Miranda, N. (2014). Implementación del Programa Nacional de Bilingüismo: un balance intermedio. Educ. Educ. 17(1), 51-67. https://doi.org/10.5294/edu.2014.17.1.3

Chapelle, C. A. (2001). Computer applications in second language acquisition. Cambridge: Cambridge University Press. https://doi.org/10.1017/CBO9781139524681

Cohen, A. D. (1994). Assessing language ability in the classroom. Boston: Heinle \& Heinle Publishers.

Council of Europe. (2001). Common European framework of reference for languages: Learning, teaching, assessment. Retrieved from https://www.coe.int/t/dg4/linguistic/source/framework_en.pdf

Correa, D., \& González, A. (2016). English in public primary schools in Colombia: Achievements and challenges brought about by national language education policies. Education Policy Analysis Archives, 24(83), 1-30. https://doi.org/10.14507/epaa.24.2459

Cronquist, K. \& Fiszbein, A. (2017). El aprendizaje del inglés en América Latina. Retrieved from https://www.thedialogue.org/wp-content/uploads/2017/09/El-aprendizaje-del-ingl\%C3\%A9s-en-Am\%C3\% A9rica-Latina-1.pdf

Dirección General de Cultura y Educación - Argentina. (2010). Diseño curricular para la educación secundaria: Inglés $5^{\circ}$ año. Retrieved from http://servicios.abc.gov.ar/lainstitucion/organismos/consejogeneral/disenios curriculares/secundaria/quinto/materias_comunes/ingles.pdf

Education First (EF). (2016). EF EPI: Índice del nivel de inglés 2016. Retrieved from http://media2.ef.com/__ / media/centralefcom/epi/downloads/full-reports/v6/ef-epi-2016-spanish-latam.pdf

García Santa-Cecilia, A. (2004). Marco común europeo de referencia para las lenguas: aprendizaje, enseñanza, evaluación. Instituto Cervantes. $\quad$ Retrieved from https://cvc.cervantes.es/ensenanza/biblioteca_ele/publicaciones_centros/PDF/bremen_2004/03_garcia.pdf

Gonzalez, P. F., Ochoa, C. A., Cabrera, P. A., Castillo, L. M., Quiñonez, A. L., ... Arias, M. O. (2015). EFL teaching in the Amazon region of Ecuador: A focus on activities and resources for teaching listening and speaking skills. English Language Teaching, 8(8), 94-103. https://doi.org/10.5539/elt.v8n8p94

Hernandez, E. (2014). El B-learning como estrategia metodológica para mejorar el proceso de enseñanza-aprendizaje de los estudiantes de inglés de la modalidad semipresencial del departamento especializado de idiomas de la Universidad Técnica de Ambato (Doctoral dissertation). Retrieved from http://eprints.ucm.es/29610/1/T35913.pdf

Instituto Nacional de Estadística e Informática (INEI). (2015). Población del 2000 al 2015. Retrieved from http://proyectos.inei.gob.pe/web/poblacion/

Inglés para la Competitividad Social. (2015). Inglés es posible: Propuesta de una agenda nacional. Retrieved from http://imco.org.mx/wp-content/uploads/2015/04/2015_Documento_completo_Ingles_es_posible.pdf

Ipsos Apoyo Opinión y Mercado S.A. (2011). Perfiles zonales de la gran Lima 2011. Retrieved from https://www.ipsos.com/sites/default/files/publication/2011-05/MKT\%20Data\%20Perfiles\%20Zonales\%202 011.pdf

Macmillan Publishers. (2015). New Inside Out Quick Placement Test. Retrieved from http://www.insideout.net/new/wp-content/uploads/2010/09/quick-placement-test.doc

Maldonado-Valentín, M. (2016). An exploration of the effects of language policy in education in a contemporary Puerto Rican society. Education Policy Analysis Archives, 24(85), 1-24. 
https://doi.org/10.14507/epaa.24.2453

Matear, A. (2008). English language learning and education policy in Chile: Can English really open doors for all?. Asia Pacific Journal of Education, 28(2), 131-147. https://doi.org/10.1080/02188790802036679

Mendoza, M. (2015). Políticas públicas educativas para la enseñanza del idioma inglés como segunda lengua: Breve estudio comparativo en Colombia, Costa Rica, México y Uruguay. Revista Latinoamericana de Educación Comparada, 8, 123-135.

Mexicanos Primero (2015). Sorry. El aprendizaje del inglés en México. Retrieved from http://www.sitioswwweb.com/miguel/jbr_Sorry-digital-ok.pdf

Ministerio de Educación de Ecuador. (2017). Fortalecimiento del Inglés: Objetivos. Retrieved from https://educacion.gob.ec/objetivos-2/

Ministerio de Educación del Perú (MINEDU). (2014a). Inglés en el marco de la JEC. Retrieved from http://jec.perueduca.pe/?dl_id=2722

Ministerio de Educación del Perú (MINEDU). (2014b). Inglés - Placement Test. Retrieved from http://jec.perueduca.pe/?page_id=1653

Ministerio de Educación del Perú (MINEDU). (2015). Normas para la implementación del modelo de servicio educativo jornada escolar completa para las instituciones educativas públicas del nivel de educación secundaria. $\quad$ Retrieved from http://www.minedu.gob.pe/a/pdf/jec/RSG-008-2015_NORMA_JEC_190115.pdf

Ministerio de Educación del Perú (MINEDU). (2016a). Listado de II.EE. por región. Retrieved from http://jec.perueduca.pe/?page_id=2764

Ministerio de Educación del Perú (MINEDU). (2016b). Manual del acompañante especializado en Inglés. Lima: Ministerio de Educación del Perú.

Ministerio de Educación del Perú (MINEDU). (2016c). Plan de implementación al 2021 de la política de enseñanza, aprendizaje y uso del idioma inglés - Inglés, puertas al mundo. Retrieved from http://www.minedu.gob.pe/ingles-puertas-al-mundo/pdf/ds-n007-2016-minedu.pdf

Ministerio de Educación del Perú (MINEDU). (2016d) Resultados de "Inglés, puertas al mundo" a junio 2016 [Infographic]. Retrieved from http://www.minedu.gob.pe/ingles-puertas-al-mundo/pdf/infografia.pdf

Ministerio de Educación del Perú (MINEDU). (2017a). Inglés, puertas al mundo. Retrieved from http://www.drelm.gob.pe/politicas/aprendizajes/ingles-para-todos

Ministerio de Educación del Perú (MINEDU). (2017b). Programación anual del área de inglés JEC. Retrieved from http://jec.perueduca.pe/?dl_id=9936

Ministerio de Educación del Perú (MINEDU). (2017c). Sesiones de aprendizaje - Área de inglés JEC. Retrieved from http://jec.perueduca.pe/?page_id=4020

Ministerio Secretaría General de la Presidencia, Ministerio de Educación \& Ministerio de Economía, Fomento y Turismo. (2014). Estrategia nacional de inglés 2014-2030. Retrieved from http://www.economia.gob.cl/wp-content/uploads/2014/03/140307-Documento-Estrategia-Nacional-de-Ingl $\% \mathrm{C} 3 \% \mathrm{~A} 9 \mathrm{~s}-2014-2030 . \mathrm{pdf}$

Morales, S. \& Ferreira, A. (2008). La efectividad de un modelo de aprendizaje combinado para la enseñanza del inglés como lengua extranjera: Estudio empírico. Revista de Lingüística Teórica y Aplicada, 2(46), 95-118.

Moskal, P., Dziuban, C. \& Hartman, J. (2012). Blended learning: A dangerous idea? The Internet and Higher Education, 18, 15-23.

Nunan, D. (1992). Research methods in language learning. Nueva York, NY: Cambridge University Press.

Ochoa, C. \& Roberto, E. (2011). Blended learning in the teaching of English as a foreign language: An educational challenge. HOW Journal, 18(1), 154-168.

Plan Ceibal. (2017). Evaluación Adaptativa de Inglés 2016- Resumen Ejecutivo. Retrieved from http://www.anep.edu.uy/sea/wp-content/uploads/2017/08/Resumen-ejecutivo-2016.pdf

Plan Ceibal. (2018). Qué es Plan Ceibal. Retrieved from https://www.ceibal.edu.uy/es/institucional

Porto, M. (2016). English language education in primary schooling in Argentina. Education Policy Analysis Archives, 24(80), 1-29. https://doi.org/10.14507/epaa.24.2450 
Quesada, A. (2013). La enseñanza y aprendizaje del idioma inglés: la investigación y su impacto en la realidad costarricense. Revista de Lenguas Modernas, 19, 393-408.

Ramírez-Romero, J., Pamplón, E., \& Cota, S. (2012). Problemática de la enseñanza del inglés en las primarias públicas de México: Una primera lectura cualitativa. Revista Iberoamericana de Educación, 60(2), 1-12.

Ramírez-Romero, J. \& Sayer, P. (2016). The teaching of English in public primary schools in Mexico: More heat than light? Education Policy Analysis Archives, 24(84), 1-25. https://doi.org/10.14507/epaa.24.2502

Richards, J. C. (2001). Curriculum development in language teaching. Cambridge: Cambridge University Press. https://doi.org/10.1017/CBO9780511667220

Sánchez-Jabba, A. (2013). Bilingüismo en Colombia. Retrieved from http://www.banrep.gov.co/docum/Lectura_finanzas/pdf/dtser_191.pdf

Yasar, I. \& Demirkolb, M. (2014). Effect of blended learning environment model on high school students' academic achievement. The Turkish Online Journal of Educational Technology, 3(1), 78-87.

\section{Copyrights}

Copyright for this article is retained by the author(s), with first publication rights granted to the journal.

This is an open-access article distributed under the terms and conditions of the Creative Commons Attribution license (http://creativecommons.org/licenses/by/4.0/). 